\section{The Driverless City}

By Ralph Wanger, CFA

There has been a lot of excitement recently about the prospects for driverless cars. These vehicles involve very interesting technology, combining sensors and activators; elaborate software; fast, cheap computers; and GPS location systems. The hardware and software to operate this new generation of vehicles are quite far along. Major players include the existing automobile companies plus such new entrants as Tesla, Google, and Apple. There are still some software kinks to smooth out-for example, it is hard for the computers to decide whether someone by the side of the road intends to cross the street or is just hanging out. Sensors can be impaired by bad weather, such as snow, sleet, rain, or fog. Given the number of competitors working on these problems, I suspect they will be solved in the next couple of years.

What effects will driverless cars have on society? How will they change the physical structure of cities as this revolution proceeds? I had lunch recently with two academics who have been studying these questions: Marshall Brown and Ron Henderson, both professors at the Illinois Institute of Technology College of Architecture. As team members of the Driverless City Project, they had some interesting ideas to share.

\section{THE NEW CITYSCAPE}

Anything involving cars has to involve parking. For faculty members of an urban university, the most important thing is not salary or teaching load but simply having a regular parking place. Architecture professors want to make major improvements in parking systems. All of us professional investors who work in a big city surely agree that parking is ridiculously expensive and that people driving around looking for parking spots clog up the streets and block traffic. People who use taxis and Uber might escape the parking problem, but these services are expensive.

If your driverless car could park itself in a big, multistory garage a few miles away from your office and show up back at your door in three minutes, life would be better. There would be lower cost, less congestion, and the car could recharge its battery during the day.

I have already mentioned how parking influences architecture. Any architect would love to replace the multi-acre asphalt parking lot surrounding shopping malls or football stadiums. Architectural aesthetics could be improved by cars that can be directed to store themselves in high-rise garages a couple of miles from the ballpark and return at the end of the game.

Do you need a garage next to or in your house? Maybe not. Could your home office be set up as a detachable, mobile pod that could drive itself downtown? That might work very well, or it might be just as easy to eliminate your downtown office and do all of your work from home. Then, when there

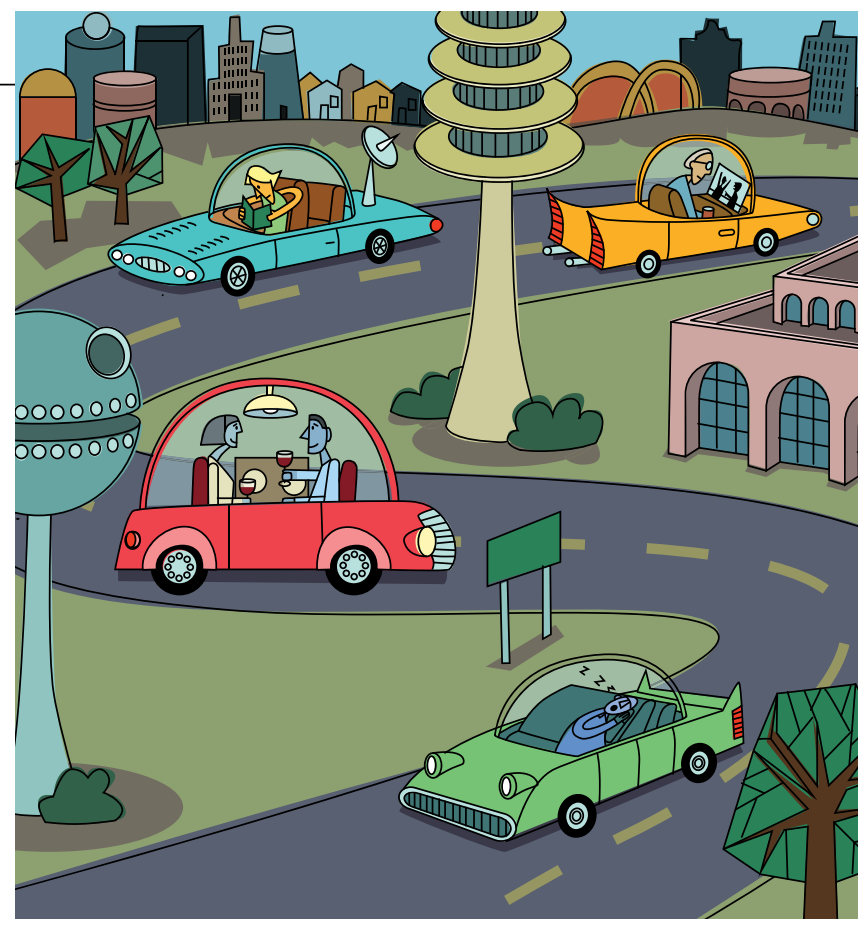

was a big staff meeting, everybody could drive their home offices to a central facility and create a temporary office building for the afternoon-overnight camp for your home office.

\section{TRANSITION PROBLEMS}

All the houses, roads, and vehicles we have now represent a great deal of capital and a truckload of tradition. There is a serious turf war already going on between established taxi drivers and the upstart Uber drivers. Most professional drivers are not middle class. Driving jobs provide good entrylevel positions for some people. For many people (such as immigrants or parts of the working class), driving a taxi or delivering pizzas are good first jobs. If these kinds of jobs disappear, there will be a lot of pushback.

Driverless vehicles are not just limited to passenger cars. Industrial and agricultural uses will be numerous. I expect major controversy regarding truck drivers. I saw an estimate recently that $10 \%$ of the American workforce makes its living by driving. Will these legacy jobholders be able to slow down the transition to driverless cars?

My guess is that there will be many problems with certain labor unions. One solution will be to keep some drivers on the payroll but not doing much, a practice known as "featherbedding." For instance, long-distance trucking companies could operate six-truck convoys that do not require six drivers but pay one person to sit in the first truck and read comic books.

\section{RE-PAVING THE WAY}

Who benefits from a driverless city? The first political group to love the new world may be the government bodies in charge of our roads. You probably live in or near a major city. You 
certainly have traffic jams. Can we build a new eight-lane freeway through an urban area in order to speed up your commute? Answer: No way! Clearing a large enough strip of land by demolishing thousands of buildings and then building a new road is undoable. And no mayor wants to face the neighborhood activists, environmentalists, and classaction lawyers who would be blocking the project. Even if these obstacles could be overcome, there is just no way to finance a new highway.

No, we are going to have to live with the road structure we have now. But what the new cars will allow us to do is modify existing roads. For instance, a three-lane highway with 13-foot-wide lanes needs 39 feet of pavement. With more precise automated driving eliminating human lane-weaving, lanes could be narrower. Repainting the lanes could easily divide the same width of road into four nine-foot lanes. Tighter spacing between cars would be scary at first, but we could get used to it. If we can fit three times the number of cars on roads and travel at higher speeds, we won't need more roads. Overhead lighting, traffic signals, and traditional speed limits are some other things that could be removed from roads.

What will convince people who really enjoy driving to switch over? First, cost. Insurance would be dramatically cheaper for driverless cars because the accident rate would plummet. Every year, 30,000 people are killed in auto-related accidents, with hundreds of thousands more injured. In the driverless city, deaths would be rare. Arresting people for driving under the influence would become obsolete.

The new technology will also offer advantages to people doing long-distance driving. Today, if you want to go from Chicago to St. Louis, it might take five hours if you drive yourself, but in a driverless car in a designated lane, it might take only three hours. I think all of these advantages, when combined, will persuade most people in the United States that the driverless city is faster, cheaper, and safer than what we have now. Although there will still be many of us who want the thrill of driving, we can always go to a race track and indulge our hobby. Cars will be an attractive sentimental relic of the past, enjoyed by people the same way horses and sailboats are today.

\section{DRIVING SOCIAL CHANGE}

There are any number of other problems driverless cars might solve. For instance, one of the events an elderly person most dreads is the day the kids say, "You shouldn't drive anymore." Today, that is a life sentence of house arrest. But with driverless cars, that conversation never has to happen.

Additionally, parents expend an enormous amount of time driving kids to school, orthodontists, and soccer games. Some parents would happily let their older children use a driverless car for these trips and use that time to live their own lives.

Furthermore, worries about people using their cellphones while driving will disappear. In a driverless car, you can use your phone or computer, play a video game, read a comic book, or take a nap.

\section{INVESTMENT IMPLICATIONS}

Given all the revolutionary changes, investors will be most interested in one question: What will driverless cars mean for investable companies and industries?

AUTOMOBILE MANUFACTURERS With cars being mostly electric and managed in large fleets, the main differentiating feature between them will be the entertainment systemprobably similar to your media room at home, with a television, stereo, and video games. When we fly, most of us do not care if we are in a Boeing 787 or an Airbus A320, but we do care how close the seat rows are to each other or which movie is available. So, making cars will be poorly rewarded, but writing the software will be exciting.

INSURANCE As previously mentioned, auto insurance will get cheaper. There will be very few accidents, so there will be few large losses and little underwriting to do. My daughter has just joined a group at Allstate Insurance that is redefining the company's place in the driverless city.

HEALTH CARE If there are several hundred thousand fewer accidents each year, hospital emergency rooms will be a lot quieter. Hospitals may need redesigning as the patient census moves to the elderly. And there may be a shortage of organ donors.

REAL ESTATE Switching to driverless cars will reshape the world in the same way that switching to the horseless carriage did a century ago. That switch led to redrawing the US real estate map by replacing hub-and-spoke cities (New York City, Boston, Chicago) with places that are more spread out, such as Los Angeles, Phoenix, Houston, and Silicon Valley. The trillions in capital tied up in existing houses and buildings will soon not be optional. Existing real estate values may drop, and new forms may spring up. (There is already a trend in Silicon Valley to live in San Francisco instead of Cupertino.) One of the worst things about cities is traffic jams; the driverless city will be less congested and thus a nicer place to live. However, the worst thing about suburbs is being boring. Cities will grow faster; suburbs, slower.

TRAVEL AND TOURISM New travel systems can be invented. Could 1,000 cars drive to Seattle, assemble themselves into a cruise ship, sail to Alaska, disassemble into cars for separate touring for a week, and then reassemble for the voyage home? A crazy idea? Probably, but technological change can make some crazy ideas that actually work.

As our transportation system mutates into a tightly linked fleet of cars monitored by artificial intelligence, a lot will happen. The architecture of city layouts, buildings, and houses will change. The kind of jobs people do will change. There will be issues of liberty in a structured environment for most adults but additional mobility for kids and their grandparents. All these changes will destroy some of today's industries (automobile insurance) and help others (tourism). As a part of the financial system, you can have a great career if you identify the winners and losers.

Ralph Wanger, CFA, is a trustee of Columbia Acorn Trust. 